\title{
Review
}

Urologia

Internationalis

Abhishek Trehan

Medical Sciences Division, University of Oxford, Lincoln College, Oxford, UK
Published online: July 2, 2014

\section{Comparison of Off-Clamp Partial Nephrectomy and On-Clamp Partial Nephrectomy: A Systematic Review and Meta-Analysis}

\section{Key Words}

Nephrectomy · Partial nephrectomy · Ischaemia · Renal clamping $\cdot$ Renal tumours

\section{Abstract}

Objective: To compare peri- and postoperative variables, surgical complications, oncological outcomes and renal outcomes of off-clamp partial nephrectomy (PN) and on-clamp PN. Methods: A systematic search of the electronic databases, including MEDLINE, Embase and Cochrane Library, was performed. The pooled estimates of tumour size, operative time, estimated blood loss, length of stay, overall complications, transfusion rates, urinary leaks, positive surgical margins and eGFR were calculated. Results: 14 studies were included. There was no significant difference between offclamp PN and on-clamp PN in terms of tumour size, operative time, estimated blood loss, length of stay, overall complications, transfusion rates, urinary leaks, and positive surgical margins. However, a non-statistically significant trend towards increased blood loss ( $p=0.12$ ) and transfusion rates $(p=0.07)$ in those undergoing off-clamp PN was noted. Off-clamp PN was associated with a significantly lower reduction in eGFR than on-clamp PN (standardised weighted mean difference $0.27,95 \% \mathrm{Cl} 0.14,0.40, \mathrm{p}<0.0001$ ). Conclusions: Off-clamp PN may be associated with im- proved long-term renal outcomes when compared to onclamp PN with no difference in in peri- and postoperative variables, surgical complications and oncological outcomes. However, the meta-analysis was limited by the design of the underlying studies, and hence further work is necessary.

(c) 2014 S. Karger AG, Basel

\section{Introduction}

In light of the increasing evidence to suggest that when compared to radical nephrectomy, partial nephrectomy $(\mathrm{PN})$ is associated with similar oncological outcome, reduced incidence of chronic kidney disease (CKD) and increased overall survival, $\mathrm{PN}$ is increasingly gaining popularity over radical nephrectomy [1-3].

A recent area of particular interest with regard to $\mathrm{PN}$ is whether or not clamping of the renal hilum should be undertaken. On the one hand, clamping of the renal hilum during $\mathrm{PN}$ is traditionally undertaken with the intention of minimising blood loss and allowing for bloodless dissection, which would be hoped to improve visualisation and hence reduce the incidence of positive surgical margins and aid in renorrhaphy [4]. On the other hand however, it has been suggested that renal ischaemia can impair renal function on both a short- and long-term ba-

\section{KARGER}

E-Mail karger@karger.com www.karger.com/uin (c) 2014 S. Karger AG, Basel

0042-1138/14/0932-0125\$39.50/0
Abhishek Trehan

Medical Sciences Division

University of Oxford, Lincoln College

Turl Street, Oxford OX1 3DR (UK)

E-Mail abhishek.trehan@ lincoln.ox.ac.uk 


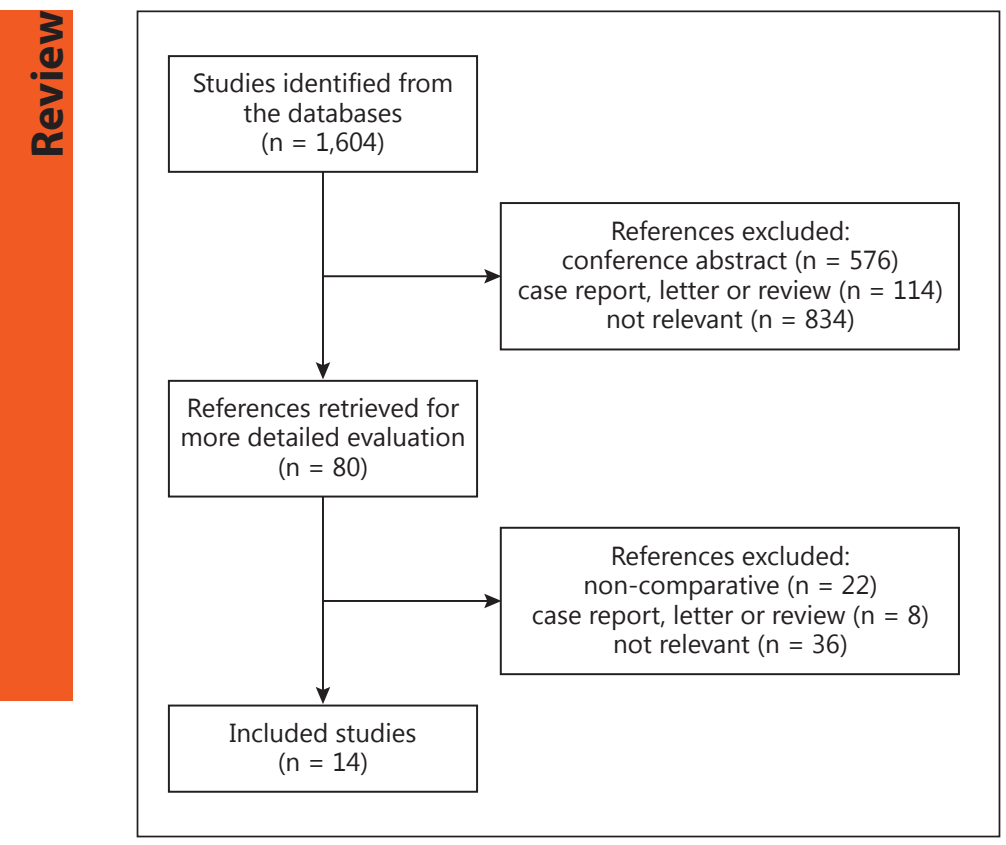

Fig. 1. Flow diagram of studies identified, included and excluded.

sis. Perhaps the most compelling evidence in support of this was presented by Thompson et al. [5] who, in their observational study with multivariate analysis, found that longer warm ischaemia time is associated with both acute renal failure (ARF) and $\mathrm{CKD}$, leading to the conclusion that 'every minute [of renal hilum clamping] counts'.

In a bid to mitigate these potentially negative effects on renal function, performing $\mathrm{PN}$ in the absence of renal ischaemia by not clamping the renal pedicle has been advocated. The aim of this meta-analysis is to compare offclamp PN to on-clamp PN.

\section{Methods}

A systematic search of the electronic databases MEDLINE and Embase was performed using the OVID SP interface and of The Cochrane Library using the PubMed interface. The following search query of all available fields was utilised: nephrectomy AND (clamp* OR ischaemia).

The inclusion criteria for this meta-analysis were comparative studies comparing off-clamp to completely on-clamp PN. Studies involving partial/segmental renal artery clamping were not included. The following exclusion criteria were used: (i) conference abstract; (ii) case report, letter or review; (iii) off-clamp PN noncomparatively described; (iv) does not meet the inclusion criteria. Where two studies were published by the same group with overlapping patient populations, the most recent study was used. The following information was extracted from each study: first author, year of publication, number of patients, warm ischaemia time (WIT), means of group allocation, surgical approach, estimated blood loss, operative time, length of hospital stay, overall complications (including transfusions), transfusions, urinary leak, positive surgical margins, recurrence, and renal function outcomes.

A meta-analysis comparing off-clamp to on-clamp PNs was undertaken. The risk ratio (RR) was used for binary outcomes and weighted mean difference (WMD) or standardised weighted mean difference (SWMD) for continuous variables. RRs were calculated as off-clamp risk relative to on-clamp risk; thus $\mathrm{RR}>1$ indicates greater risk in off-clamp group, and $\mathrm{RR}<1$ indicates greater risk in on-clamp group. Mean differences were calculated as off-clamp minus on-clamp; thus positive mean differences reflect a greater off-clamp value for that variable, and negative mean differences reflect a greater on-clamp value for that variable. A random effects model was utilised throughout in light of study heterogeneity $\left(\mathrm{I}^{2}\right.$ $>50 \%$ for most variables). Data analysis was performed with Review Manager (RevMan 5.2, Cochrane Collaboration, Oxford, UK). Where outcomes which were continuous variables were stated as medians and range, the methods described by Hozo et al. [6] were utilised in order to estimate the mean and standard deviation. Estimates of standard deviation were not made for continuous variables where no measure of data spread was provided.

\section{Results}

A total of 1,604 search results were retrieved, of which 14 studies were included in this meta-analysis (fig. 1). The characteristics of the included studies are shown in table 1. All studies were observational cohort studies other than Kondo et al. [10], which was stated to allocate patients randomly although no further details on this allocation were provided in the study.

\section{Meta-Analysis of Tumour Size}

There was overall no significant difference in tumour size between patients undergoing off-clamp and on-clamp $\mathrm{PN}$ (WMD $-0.25 \mathrm{~cm}, 95 \% \mathrm{CI}-0.52,0.03, \mathrm{p}=0.08$ ) (fig. 2).

\section{Meta-Analysis of Peri- and Postoperative Variables}

Both groups had similar operative time (WMD 1.69 $\min , 95 \% \mathrm{CI}-17.93,21.32, \mathrm{p}=0.87$ ) (fig. 3), estimated blood loss (WMD $89.76 \mathrm{ml}, 95 \% \mathrm{CI}-23.70,203.23, \mathrm{p}=$ 0.12 ) (fig. 4), and length of stay (WMD 0.31 days, $95 \%$ CI $-0.89,1.50, \mathrm{p}=0.61$ ) (fig. 5).

\section{Meta-Analysis of Surgical Complications}

Both groups had similar overall complication rates (RR 0.87, 95\% CI 0.51, 1.46, p = 0.59) (fig. 6), transfusion rates (RR 1.49, 95\% CI 0.97, 2.28, p = 0.07) (fig. 7), and incidence of urinary leaks (RR $0.55,95 \%$ CI $0.24,1.27$, $\mathrm{p}=0.16)$ (fig. 8). 
Table 1. Characteristics of included studies [7-20]

\begin{tabular}{|c|c|c|c|c|c|c|c|}
\hline $\begin{array}{l}\text { Reference } \\
\text { (first author) }\end{array}$ & $\begin{array}{l}\text { Number of } \\
\text { patients } \\
\text { off-clamp/ } \\
\text { on-clamp }\end{array}$ & $\begin{array}{l}\text { Mean WIT, } \\
\text { min }\end{array}$ & Group allocation & $\begin{array}{l}\text { Surgical } \\
\text { approach }\end{array}$ & $\begin{array}{l}\text { Assessment of renal } \\
\text { function }\end{array}$ & Renal outcomes reported & $\begin{array}{l}\text { Mean follow-up, } \\
\text { months }\end{array}$ \\
\hline $\begin{array}{l}\text { Guillonneau, } \\
2003[8]\end{array}$ & $12 / 16$ & $\begin{array}{l}27.3 \pm 7 \\
(15-47)^{\dagger}\end{array}$ & not stated & $\begin{array}{l}\text { laparo- } \\
\text { scopic }\end{array}$ & serum [creatinine] & $\begin{array}{l}\text { 1. change in [creatinine] } \\
(\mathrm{mg} / \mathrm{dl})\end{array}$ & 1 \\
\hline $\begin{array}{l}\text { Kobayashi, } \\
2008[9]\end{array}$ & $13 / 7$ & $\begin{array}{l}35 \\
(25-40)\end{array}$ & not stated & $\begin{array}{l}\text { laparo- } \\
\text { scopic }\end{array}$ & $\begin{array}{l}\text { serum [creatinine] } \\
\text { and MAG3 renal } \\
\text { scintigraphy }\end{array}$ & $\begin{array}{l}\text { 1. change in [creatinine] } \\
(\mathrm{mg} / \mathrm{dl}) ; 2 . \text { change in renal } \\
\text { scan }(\%)\end{array}$ & $\begin{array}{l}\text { NA for } \\
\text { [creatinine]; } \\
\text { renal scan } \\
<3 \text { months }\end{array}$ \\
\hline $\begin{array}{l}\text { Kondo, } \\
2002[10]\end{array}$ & $10 / 24$ & $\mathrm{NA}^{\dagger}$ & $\begin{array}{l}\text { random selection (details } \\
\text { not specified) }\end{array}$ & open & $\begin{array}{l}\text { DMSA renal } \\
\text { scintigraphy }\end{array}$ & $\begin{array}{l}\text { 1. postoperative DMSA } \\
\text { uptake (\%) }\end{array}$ & NA \\
\hline $\begin{array}{l}\text { Kopp, } \\
2012[12]\end{array}$ & $64 / 164$ & $24.5 \pm 4.6$ & not stated & open & serum [creatinine] & $\begin{array}{l}\text { 1. number of patients with } \\
\text { eGFR }<60\end{array}$ & $\begin{array}{l}\text { off-clamp 24.7; } \\
\text { on-clamp 53.6 }\end{array}$ \\
\hline $\begin{array}{l}\text { Martin, } \\
2012[13]\end{array}$ & $4 / 32$ & $\begin{array}{l}32 \pm 10 \\
(14-53)\end{array}$ & not stated & $\begin{array}{l}\text { laparo- } \\
\text { scopic } \\
\text { and } \\
\text { robotic }\end{array}$ & $\begin{array}{l}\text { serum [creatinine] } \\
\text { and renal scan } \\
\text { (method not } \\
\text { defined) }\end{array}$ & $\begin{array}{l}\text { 1. change in eGFR } \\
(\mathrm{ml} / \mathrm{min}) ; 2 \text { change in } \\
\text { renal scan }(\%)\end{array}$ & 13.7 \\
\hline $\begin{array}{l}\text { Nadu, } \\
2005[14]\end{array}$ & $16 / 29$ & $\begin{array}{l}28 \\
(20-43)\end{array}$ & tumour characteristics & $\begin{array}{l}\text { laparo- } \\
\text { scopic }\end{array}$ & - & - & - \\
\hline $\begin{array}{l}\text { Petrasz, } \\
2012[15]\end{array}$ & $13 / 25$ & $\begin{array}{l}18.4 \\
(3-35)\end{array}$ & $\begin{array}{l}\text { all cases began off-clamp; } \\
\text { converted to on-clamp on } \\
\text { demand }\end{array}$ & $\begin{array}{l}\text { laparo- } \\
\text { scopic }\end{array}$ & serum [creatinine] & $\begin{array}{l}\text { 1. postoperative } \\
\text { [creatinine] and change } \\
\text { in [creatinine] }(\mathrm{mg} / \mathrm{dl})\end{array}$ & NA \\
\hline $\begin{array}{l}\text { Tanagho, } \\
2012 \text { [18] }\end{array}$ & $29 / 29$ & $14.7 \pm 6.2$ & $\begin{array}{l}\text { retrospectively matched } \\
29 \text { off-clamp patients with } \\
29 \text { on-clamp patients with } \\
\text { identical nephrometry } \\
\text { scores and comparable } \\
\text { baseline Charlson } \\
\text { Comorbidity Index }\end{array}$ & robotic & serum [creatinine] & $\begin{array}{l}\text { 1. postoperative } \\
\text { [creatinine] and change } \\
\text { in [creatinine] }(\mathrm{mg} / \mathrm{dl}) \text {; } \\
\text { 2. postoperative eGFR and } \\
\text { change in eGFR }(\mathrm{ml} / \mathrm{min})\end{array}$ & $\begin{array}{l}\text { off-clamp: } 9.5 \\
\text { on-clamp: } 8.6\end{array}$ \\
\hline $\begin{array}{l}\text { Thompson, } \\
2010[19]\end{array}$ & $96 / 362$ & $\begin{array}{l}21 \\
(4-55)\end{array}$ & not stated & $\begin{array}{l}\text { open } \\
\text { and } \\
\text { laparo- } \\
\text { scopic }\end{array}$ & serum [creatinine] & $\begin{array}{l}\text { 1. number of patients with } \\
\text { ARF; } 2 \text {. number of patients } \\
\text { with CKD }\end{array}$ & $\begin{array}{l}\text { acute NA; } \\
\text { chronic } 39.6\end{array}$ \\
\hline $\begin{array}{l}\text { Wszolek, } \\
2011[20]\end{array}$ & $75 / 29$ & $\begin{array}{l}25 \pm 14 \\
(8-60)\end{array}$ & surgeon preference & open & serum [creatinine] & 1. change in eGFR (\%) & $\begin{array}{l}\text { early } 0-3.3 \text {; } \\
\text { late } 3.3-12\end{array}$ \\
\hline
\end{tabular}

${ }^{\dagger}$ Cold ischaemia. ${ }^{*}$ Renal artery only (not vein) clamped.

Off-Clamp Partial Nephrectomy:

A Systematic Review and Meta-Analysis 


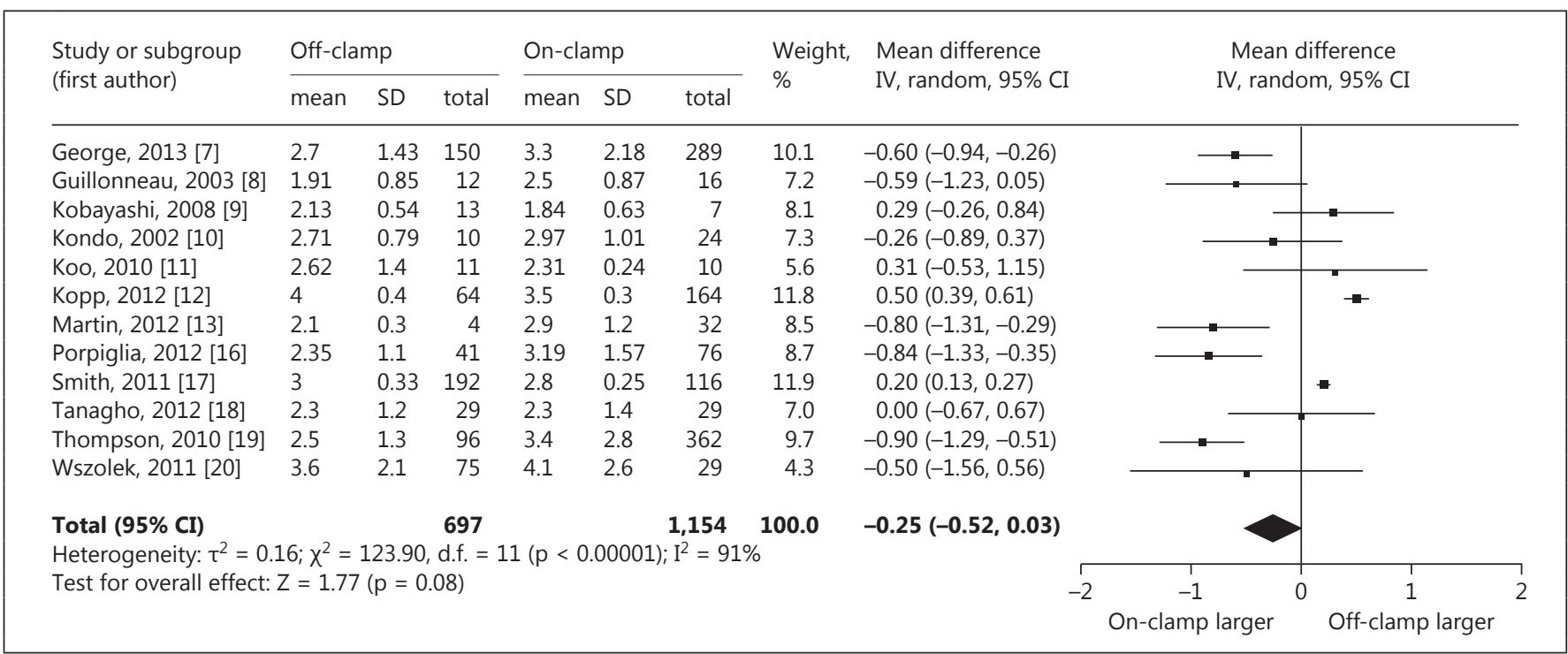

Fig. 2. Meta-analysis of tumour size.

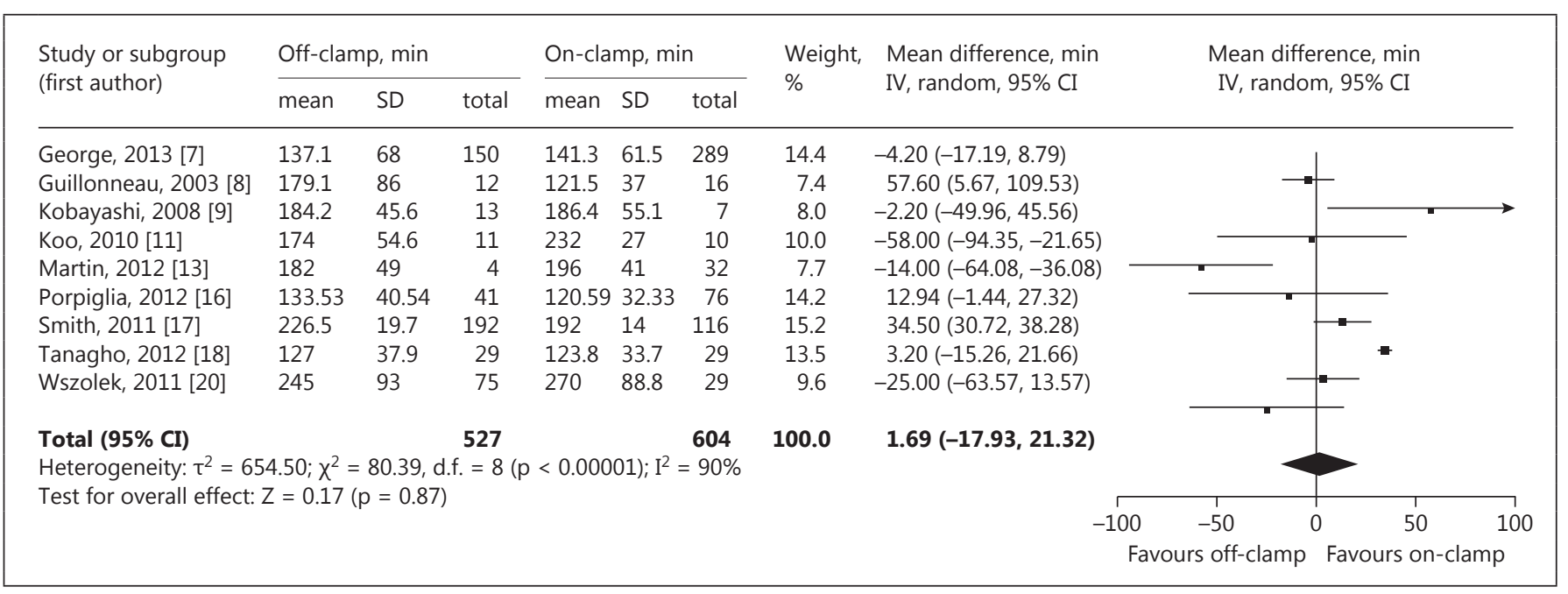

Fig. 3. Meta-analysis of operative time.

\section{Meta-Analysis of Oncological Variables}

Both groups had a similar incidence of positive surgical margins (RR 0.61, 95\% CI 0.34, 1.08, p = 0.09) (fig. 9). Only 1 study reported recurrence rates and this was similar in both groups $(\mathrm{p}=0.60)$ [17].

\section{Meta-Analysis of Renal Outcomes}

SWMD was used to assess renal outcomes as the studies varied in their time of follow-up, and 1 study reported change in eGFR in terms of a percentage not absolute units. There was a significantly lower reduction in eGFR associated with off-clamp than on-clamp PN (SWMD $0.27,95 \%$ CI $0.14,0.40, \mathrm{p}<0.0001$ ) (fig. 10).

When repeating tumour size analysis for only the 6 studies included in this eGFR analysis, there was no significant difference in tumour size between groups (WMD $-0.43 \mathrm{~cm}, 95 \%$ CI $-0.92,0.07, \mathrm{p}=0.09$ ) (fig. 11).

The meta-analysis only included 6 of the 14 studies included in this study due to 1 study not assessing renal function and the remaining 7 studies not providing suf- 


\begin{tabular}{|c|c|c|c|c|c|c|c|c|c|c|}
\hline \multirow{2}{*}{$\begin{array}{l}\text { Study or subgroup } \\
\text { (first author) }\end{array}$} & \multicolumn{3}{|c|}{ Off-clamp, ml } & \multicolumn{3}{|c|}{ On-clamp, $\mathrm{ml}$} & \multirow{2}{*}{$\begin{array}{l}\text { Weight, } \\
\%\end{array}$} & \multirow{2}{*}{$\begin{array}{l}\text { Mean difference, ml } \\
\text { IV, random, } 95 \% \mathrm{CI}\end{array}$} & \multirow{2}{*}{\multicolumn{2}{|c|}{$\begin{array}{l}\text { Mean difference, } \mathrm{ml} \\
\mathrm{IV} \text {, random, } 95 \% \mathrm{CI}\end{array}$}} \\
\hline & mean & SD & total & mean & SD & total & & & & \\
\hline George, 2013 [7] & 338.4 & 275 & 150 & 276.8 & 208 & 289 & 12.0 & $61.60(11.48,111.72)$ & & $\rightarrow$ \\
\hline Guillonneau, 2003 [8] & 708.3 & 569 & 12 & 270.3 & 281 & 16 & 5.7 & $438.00(87.86,788.14)$ & & \\
\hline Kobayashi, 2008 [9] & 133.8 & 94.6 & 13 & 63.3 & 70.3 & 7 & 11.6 & $70.50(-2.69,143.69)$ & & 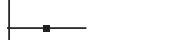 \\
\hline Kondo, 2002 [10] & 572 & 1,015 & 10 & 367 & 345 & 24 & 2.5 & $205.00(-439.06,849.06)$ & $\leftarrow$ & \\
\hline Koo, $2010[11]$ & 159 & 153 & 11 & 165 & 110 & 10 & 10.9 & $-6.00(-119.24,107.24)$ & & \\
\hline Kopp, 2012 [12] & 200 & 185 & 64 & 300 & 178 & 164 & 11.9 & $-100.00(-152.88,-47.12)$ & $\because$ & \\
\hline Martin, 2012 [13] & 288 & 218 & 4 & 150 & 99 & 32 & 8.5 & $138.00(-78.37,354.37)$ & & \\
\hline Porpiglia, 2012 [16] & 201.46 & 109.81 & 41 & 164.27 & 128.68 & 76 & 12.0 & $37.19(-7.16,81.54)$ & & - \\
\hline Smith, 2011 [17] & 500 & 125 & 192 & 200 & 100 & 116 & 12.2 & $300.00(274.63,325.37)$ & & \\
\hline Tanagho, 2012 [18] & 146.4 & 99.2 & 29 & 103.9 & 81.7 & 29 & 12.0 & $42.50(-4.27,89.27)$ & & $\rightarrow$ \\
\hline Wszolek, 2011 [20] & 900 & 2,483 & 75 & 1,000 & 2,975 & 29 & 0.8 & $-100.00(-1,319.91,1,119.91)$ & $\leftarrow$ & \\
\hline \multirow{2}{*}{\multicolumn{11}{|c|}{ 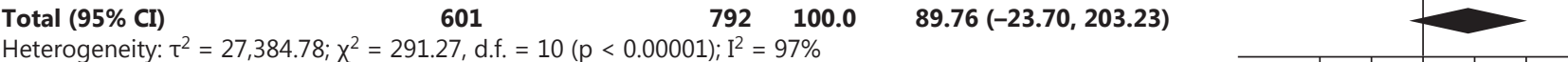 }} \\
\hline & & & & & & & & & & \\
\hline \multirow{2}{*}{\multicolumn{9}{|c|}{ Test for overall effect: $Z=1.55(p=0.12)$}} & $-200-100$ & $0 \quad 100200$ \\
\hline & & & & & & & & & $\begin{array}{l}\text { Favours } \\
\text { off-clamp }\end{array}$ & $\begin{array}{l}\text { Favours } \\
\text { on-clamp }\end{array}$ \\
\hline
\end{tabular}

Fig. 4. Meta-analysis of estimated blood loss.

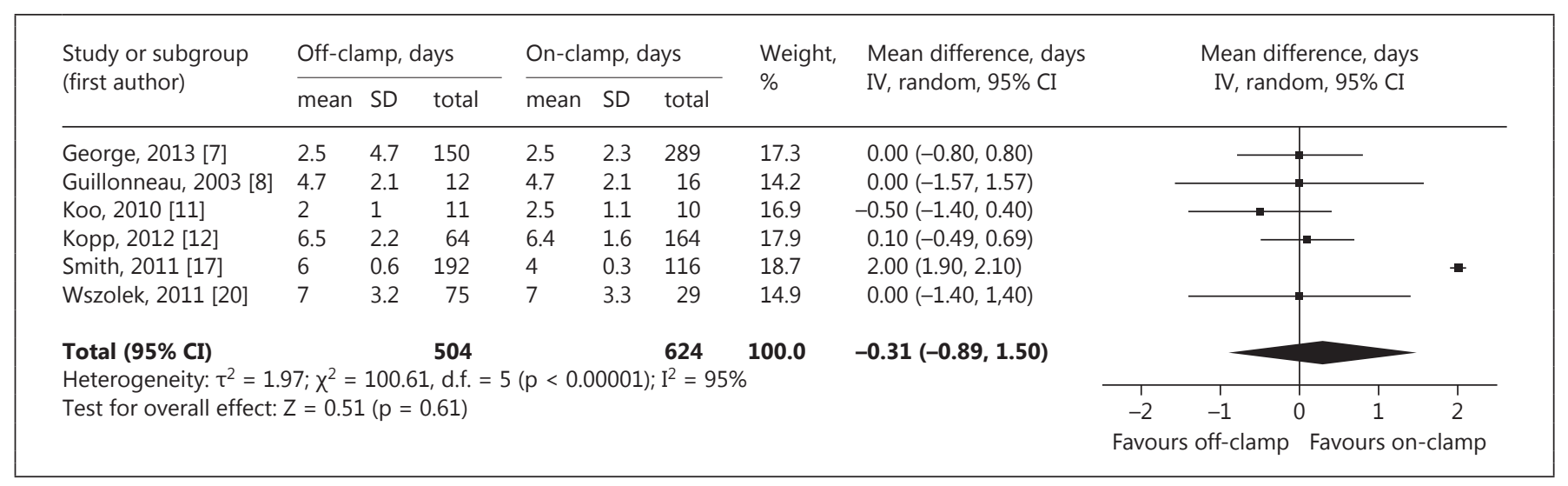

Fig. 5. Meta-analysis of length of stay.

ficient data for analysis or using outcome measures not amenable to combined analysis with change in eGFR. Key renal outcomes from these 7 studies are shown in table 2 .

\section{Discussion}

This meta-analysis included 14 studies comparing off-clamp PN with on-clamp PN. No significant difference was found between off-clamp and on-clamp PN in terms of operative time, estimate blood loss, length of stay, overall complications and urinary leak. One of the main potential drawbacks of off-clamp PN is a theoreti- cal risk of increase in blood loss and hence transfusion rates; whilst not statistically significant, the meta-analysis demonstrated a trend towards increased blood loss $(\mathrm{p}=0.12)$ and transfusion rates $(\mathrm{p}=0.07)$ in the offclamp group. Impaired visualisation due to bleeding is noted as a potential disadvantage associated with offclamp PN; the present meta-analysis did not find this to have impact on positive margins, however the use of intraoperative ultrasound may be of use to improve visualisation [21, 22].

Meta-analysis of 6 comparative studies found there was a significantly lower fall in eGFR in patients who had undergone off-clamp PN as opposed to on-clamp PN. Of the 


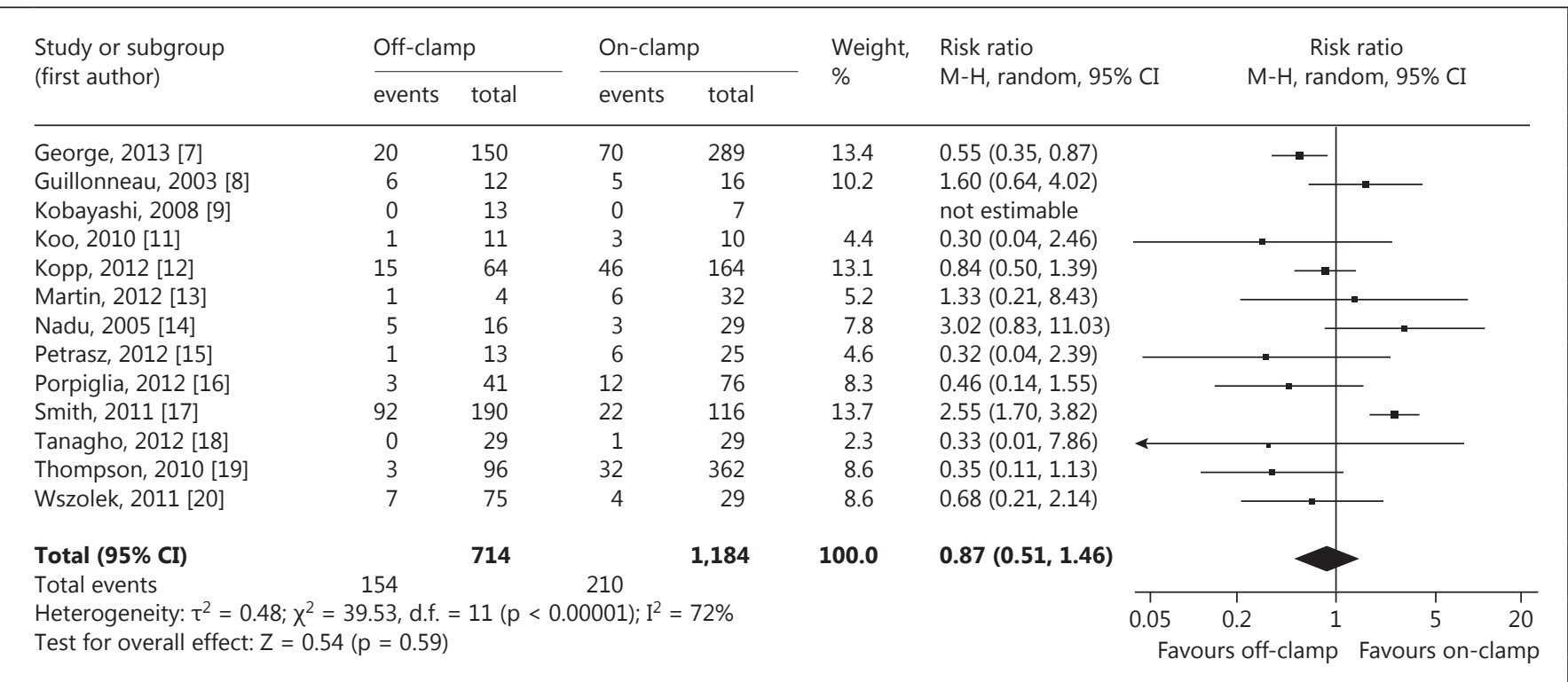

Fig. 6. Meta-analysis of overall complications.

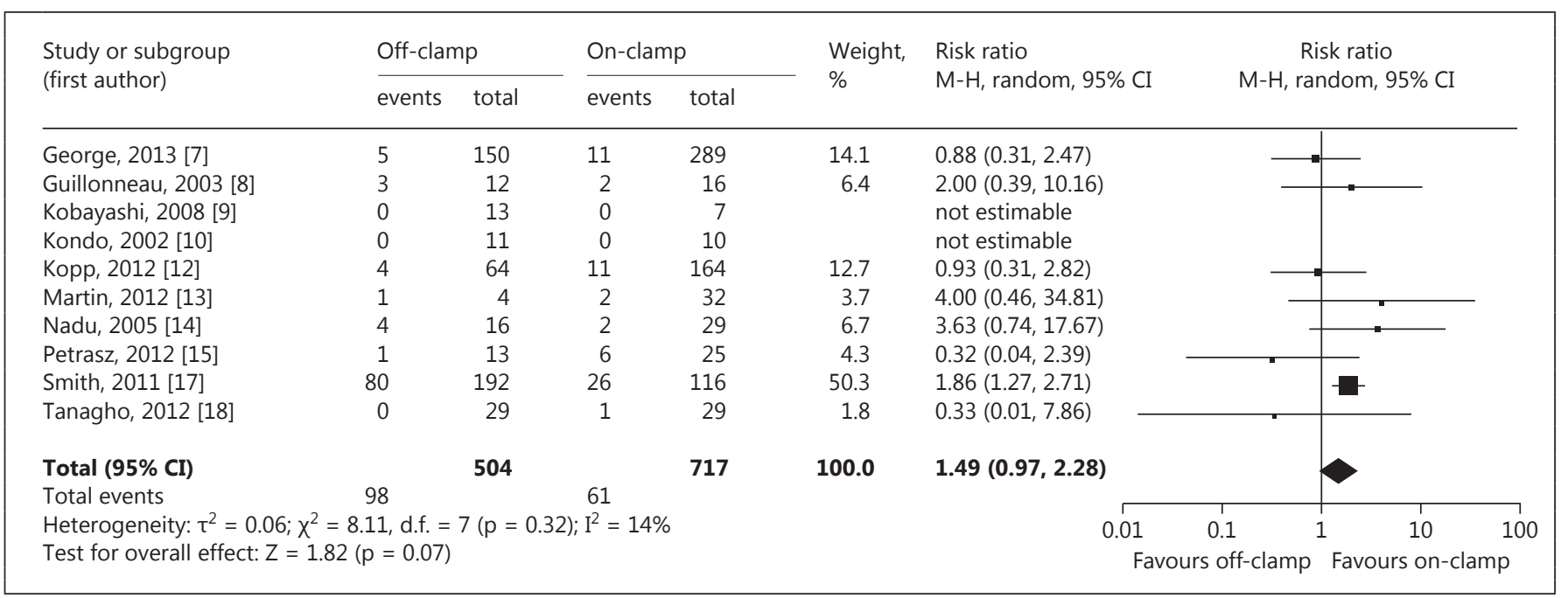

Fig. 7. Meta-analysis of blood transfusion rates.

other 7 comparative studies which were not included in the meta-analysis for change in eGFR, 4 found renal function to be superior in patients who had undergone offclamp PN (although 1 study had a significantly longer follow-up duration in the on-clamp group). Whilst the other 3 studies failed to find any statistically significant difference between off-clamp and on-clamp PN, these were all small studies (20,34 and 21 patients in total respectively).
Whilst the results of this meta-analysis suggest that off-clamp PN is associated with superior renal outcome when compared to on-clamp PN, it is worth nothing that whilst Thompson et al. [5] concluded that 'each increasing minute of warm ischaemia invites additional risk of renal consequences', George et al. [7] found that the benefit of off-clamp PN disappeared when restricting to patients with WIT of less than $30 \mathrm{~min}$. Thus, methods to 


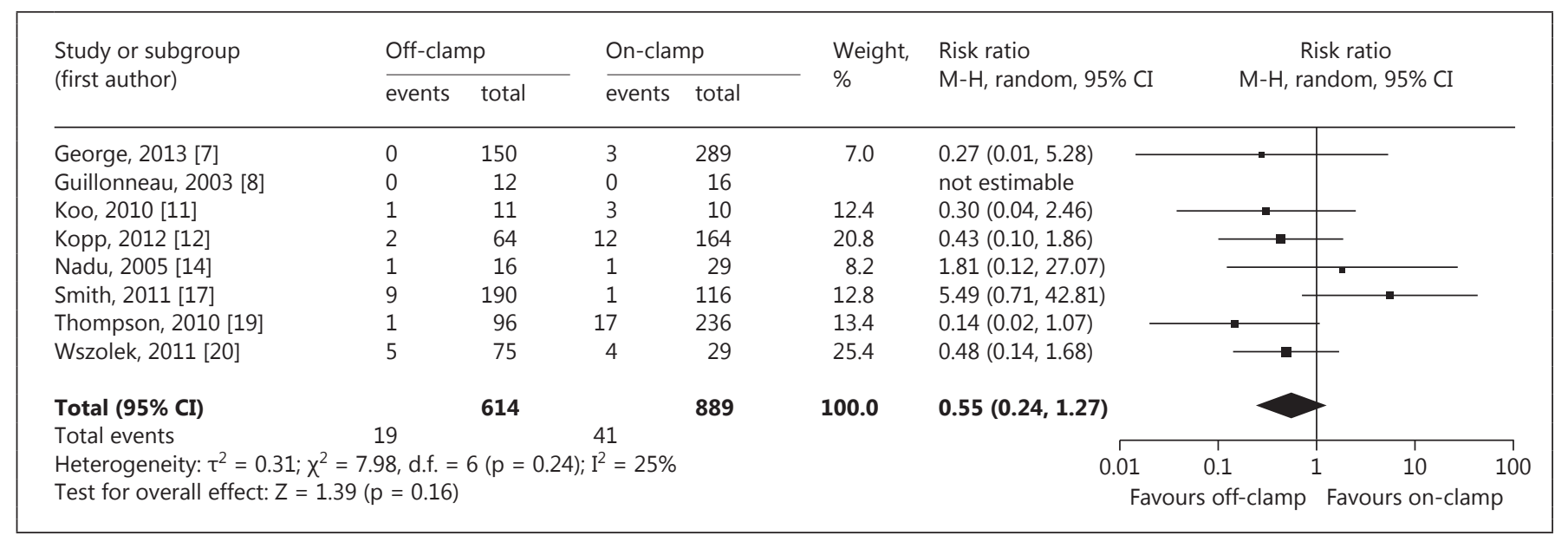

Fig. 8. Meta-analysis of urinary leaks.

\begin{tabular}{|c|c|c|c|c|c|c|c|c|c|c|}
\hline \multirow{2}{*}{$\begin{array}{l}\text { Study or subgroup } \\
\text { (first author) }\end{array}$} & \multicolumn{2}{|c|}{ Off-clamp } & \multicolumn{2}{|c|}{ On-clamp } & \multirow{2}{*}{$\begin{array}{l}\text { Weight, } \\
\%\end{array}$} & \multirow{2}{*}{$\begin{array}{l}\text { Risk ratio } \\
\mathrm{M}-\mathrm{H} \text {, random, 95\% CI }\end{array}$} & \multirow{2}{*}{\multicolumn{4}{|c|}{$\begin{array}{c}\text { Risk ratio } \\
\mathrm{M}-\mathrm{H}, \text { random, } 95 \% \mathrm{CI}\end{array}$}} \\
\hline & events & total & events & total & & & & & & \\
\hline George, 2013 [7] & 2 & 150 & 4 & 289 & 11.5 & $0.96(0.18,5.20)$ & & & & \\
\hline Guillonneau, 2003 [8] & 0 & 12 & 0 & 16 & & not estimable & & & & \\
\hline Kobayashi, 2008 [9] & 2 & 13 & 0 & 7 & 3.9 & $2.86(0.16,52.42)$ & & & & \\
\hline Koo, $2010[11]$ & 0 & 11 & 1 & 10 & 3.4 & $0.31(0.01,6.74)$ & & & & \\
\hline Kopp, 2012 [12] & 0 & 64 & 2 & 164 & 3.6 & $0.51(0.02,10.43)$ & & & & \\
\hline Martin, 2012 [13] & 0 & 4 & 1 & 32 & 3.5 & $2.20(0.10,46.89)$ & & & & \\
\hline Petrasz, 2012 [15] & 0 & 13 & 1 & 25 & 3.3 & $0.62(0.03,14.22)$ & & & & \\
\hline Porpiglia, 2012 [16] & 1 & 41 & 2 & 76 & 5.8 & $0.93(0.09,9.92)$ & & & & \\
\hline Smith, 2011 [17] & 9 & 192 & 7 & 116 & 35.4 & $0.78(0.30,2.03)$ & & $\rightarrow$ & - & \\
\hline Tanagho, 2012 [18] & 0 & 29 & 2 & 29 & 3.6 & $0.20(0.01,3.99)$ & & & & \\
\hline Thompson, 2010 [19] & 1 & 96 & 5 & 362 & 7.2 & $0.75(0.09,6.38)$ & & & & \\
\hline Wszolek, 2011 [20] & 3 & 75 & 6 & 29 & 18.8 & $0.19(0.05,0.72)$ & & 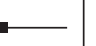 & & \\
\hline Total $(95 \%$ CI) & & 700 & & 1,155 & 100.0 & $0.61(0.34,1.08)$ & & & & \\
\hline Total events & 18 & & 31 & & & & & & & \\
\hline \multicolumn{5}{|c|}{ Heterogeneity: $\tau^{2}=0.00 ; \chi^{2}=6.10$, d.f. $=10(p=0.81) ; I^{2}=0 \%$} & & 0.01 & 0.1 & 1 & 10 & 100 \\
\hline \multicolumn{5}{|c|}{ Test for overall effect: $Z=1.71(p=0.09)$} & \multicolumn{6}{|c|}{ Favours off-clamp Favours on-clamp } \\
\hline
\end{tabular}

Fig. 9. Meta-analysis of positive surgical margins.

reduce the clamp time rather than to completely eliminate it, such as the use of 'on-demand' clamping and/or early unclamping, must also be considered [23, 24]. Other strategies to minimise renal ischaemia such as selective arterial clamping [25-27], clamping the renal artery and not the renal vein, which has been suggested to allow for limited oxygenation via venous backflow [28], and utilising cold ischaemia have also been described (although the latter is challenging during minimal access surgery) [29, $30]$.

Off-Clamp Partial Nephrectomy:

A Systematic Review and Meta-Analysis
It is also important to interpret the results of this metaanalysis with consideration of its limitations. None of the studies were randomised (although 1 study stated that patients were randomised, how this was enforced was not described). Many studies did not describe how group allocation was performed, and those that did often stated surgeon preference or allocation of smaller or exophytic tumours to the off-clamp group which would lead to significant selection bias, and although tumour size did not differ in a statistically significant manner between the off- 


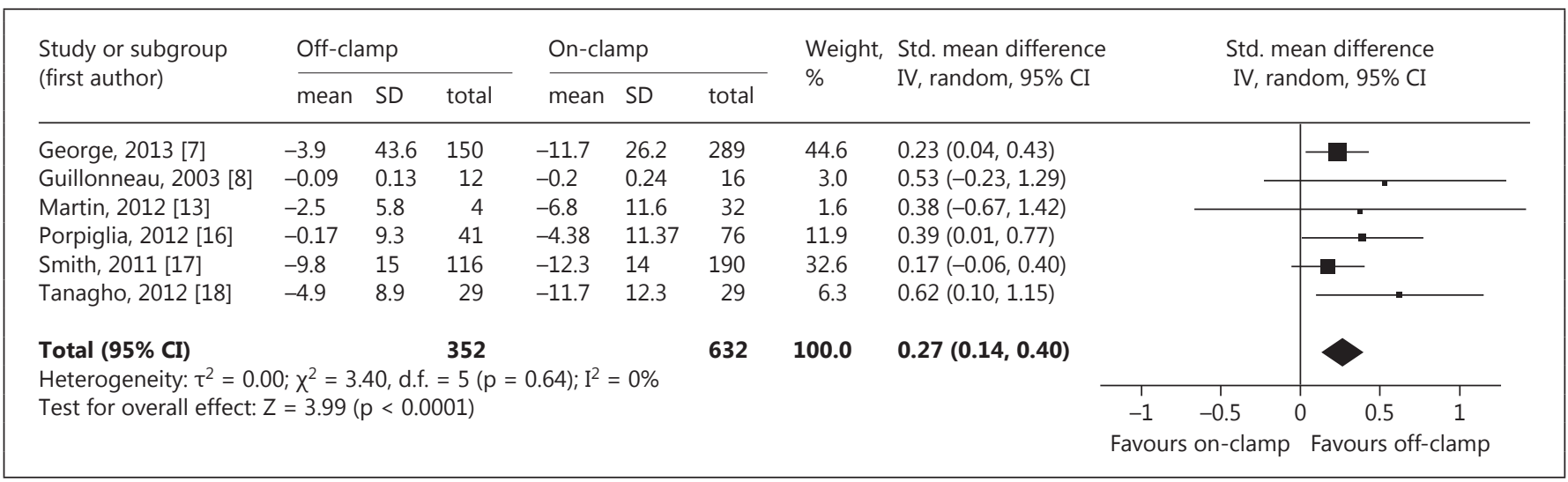

Fig. 10. Meta-analysis of change in eGFR.

\begin{tabular}{|c|c|c|c|c|c|c|c|c|c|c|}
\hline \multirow{3}{*}{$\begin{array}{l}\text { Study or subgroup } \\
\text { (first author) } \\
\text { George, } 2013 \text { [7] }\end{array}$} & \multicolumn{3}{|c|}{ Off-clamp } & \multicolumn{3}{|c|}{ On-clamp } & \multirow{3}{*}{$\begin{array}{l}\text { Weight, } \\
\% \\
18.1\end{array}$} & \multirow{3}{*}{$\begin{array}{l}\text { Mean difference } \\
\text { IV, random, 95\% CI } \\
-0.60(-0.94,-0.26)\end{array}$} & \multirow{2}{*}{\multicolumn{2}{|c|}{$\begin{array}{l}\text { Mean difference } \\
\text { IV, random, } 95 \% \mathrm{CI}\end{array}$}} \\
\hline & \multirow{2}{*}{$\begin{array}{l}\text { mean } \\
2.7\end{array}$} & \multirow{2}{*}{$\begin{array}{l}\mathrm{SD} \\
1.43\end{array}$} & \multirow{2}{*}{$\begin{array}{l}\text { total } \\
150\end{array}$} & \multirow{2}{*}{$\begin{array}{l}\text { mean } \\
3.3\end{array}$} & \multirow{2}{*}{$\begin{array}{l}\text { SD } \\
2.18\end{array}$} & \multirow{2}{*}{$\begin{array}{l}\text { total } \\
289\end{array}$} & & & & \\
\hline & & & & & & & & & 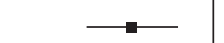 & \\
\hline Guillonneau, 2003 [8] & 1.91 & 0.85 & 12 & 2.5 & 0.87 & 16 & 14.8 & $-0.59(-1.23,0.05)$ & & \\
\hline Martin, 2012 [13] & 2.1 & 0.3 & 4 & 2.9 & 1.2 & 32 & 16.3 & $-0.80(-1.31,-0.29)$ & $\rightarrow$ & \\
\hline Porpiglia, 2012 [16] & 2.35 & 1.1 & 41 & 3.19 & 1.57 & 76 & 16.6 & $-0.84(-1.33,-0.35)$ & 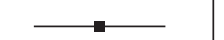 & \\
\hline Smith, 2011 [17] & 3 & 0.33 & 192 & 2.8 & 0.25 & 116 & 19.7 & $0.20(0.13,0.27)$ & & $=$ \\
\hline Tanagho, 2012 [18] & 2.3 & 1.2 & 29 & 2.3 & 1.4 & 29 & 14.5 & $0.00(-0.67,0.67)$ & & \\
\hline \multicolumn{3}{|l|}{ Total $(95 \% \mathrm{CI})$} & 428 & & & 558 & 100.0 & $-0.43(-0.92,0.07)$ & & \\
\hline \multirow{2}{*}{\multicolumn{9}{|c|}{$\begin{array}{l}\text { Heterogeneity: } \tau^{2}=0.32 ; \chi^{2}=55.11, \text { d.f. }=5 \text { ( } \\
\text { Test for overall effect: } Z=1.69(p=0.09)\end{array}$}} & & \\
\hline & & & & & & & & & $\begin{array}{ll}-0.5 & 0\end{array}$ & $0 \quad 0.5$ \\
\hline
\end{tabular}

Fig. 11. Meta-analysis of tumour size in studies included in meta-analysis of eGFR.

Table 2. Renal outcomes in studies not included in meta-analysis of eGFR

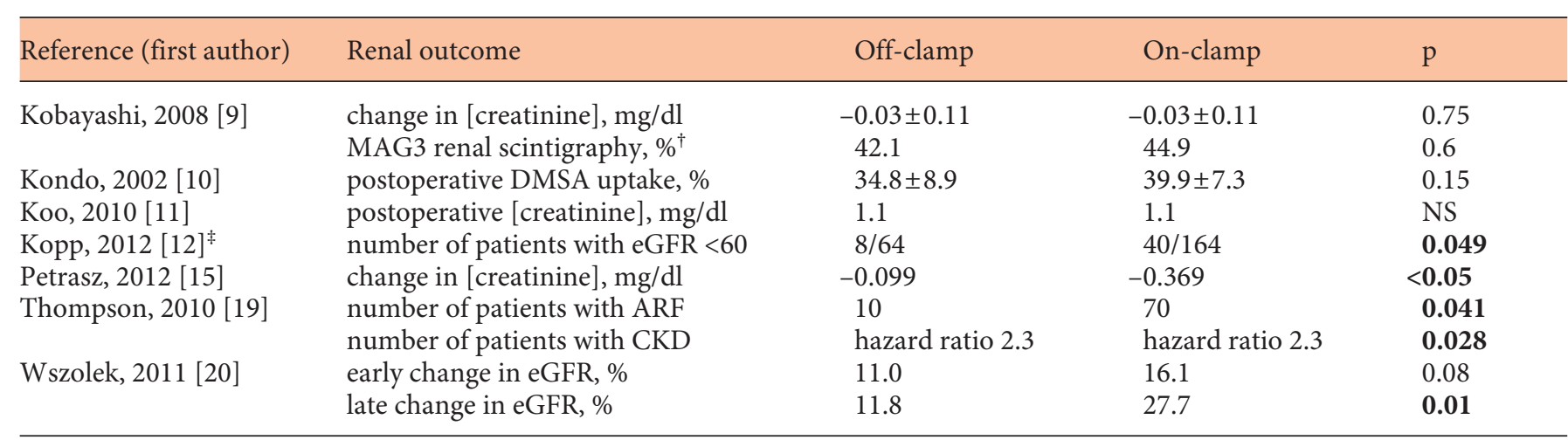

${ }^{\dagger}$ Outcome only measured in 10/23 patients in study. ${ }^{\star}$ Follow-up period: off-clamp 24.7 months, on-clamp 53.6 months. 
clamp and on-clamp groups, there was a non-statistically significant trend for smaller tumours in the off-clamp group. Insufficient studies provided information on tumour location and depth (or nephrometry scores) for analysis to be performed, which are also key determinants of tumour and hence operative complexity [31]. It has also been recently demonstrated that the percentage of parenchyma spared is a major determinant of postoperative renal function [32]; none of the studies included addressed this issue, which may be of particular importance, if for example, for a given tumour, percentage of parenchyma spared is less in off-clamp procedures due to difficultly in visualisation of tumour margins.

None of the studies made use of intention-to-treat analysis; thus if an operation originally began off-clamp, but was later converted to on-clamp in order to control bleeding, this operation would presumably be included by the study authors in the on-clamp group. Indeed, Petrasz et al. [15] began all 38 cases off-clamp, but only $13 / 38$ were completed off-clamp. Whilst off-clamp PN may be beneficial in cases which are completed off-clamp, when patients are converted to on-clamp surgery, outcomes may be inferior when compared to outcomes if the cases had begun on-clamp.

Another significant limitation of the study is that in two of the largest studies, both open and laparoscopic approaches were used, and there was differing use of these surgical approaches between off-clamp and on-clamp cases. Indeed, Thompson et al. [19] completed 92/96
(96\%) off-clamp cases by open surgery, whilst $319 / 362$ $(88 \%)$ in the on-clamp group had open surgery and the remainder laparoscopically. Smith et al. [17] completed all off-clamp cases laparoscopically, whilst in the onclamp group, 51/116 (44\%) patients had open surgery, $57 / 116(49.1 \%)$ had laparoscopic surgery and 8/116 $(0.9 \%)$ had robotic surgery. Most studies failed to state the exact follow-up period when postoperative renal function was measured for each group. Additionally, some of the studies failed to provided means and standard deviations for continuous variables and hence these were in some cases estimated from medians, ranges and interquartile ranges as described in the Methods section.

There is the need for large prospective randomised studies with long-term follow-up which compare offclamp to on-clamp PN. Measurement of pre- and postoperative renal function by DMSA or MAG3 renal scintigraphy as opposed to just eGFR via serum [creatinine] should be considered as it would allow for better discrimination of renal function.

In conclusion, the present meta-analysis suggests that off-clamp PN may be associated with improved longterm renal outcome when compared to on-clamp PN, but no difference in peri- and postoperative variables, surgical complications and oncological outcomes. However, the meta-analysis was limited by the design of the underlying studies, and hence further work is needed in order to definitively establish whether off-clamp PN confers any advantage over on-clamp PN.

References

1 Tan HJ, Norton EC, Ye Z, Hafez KS, Gore JL, Miller DC: Long-term survival following partial vs. radical nephrectomy among older patients with early-stage kidney cancer. JAMA 2012;307:1629-1635.

2 Fergany AF, Hafez KS, Novick AC: Longterm results of nephron sparing surgery for localized renal cell carcinoma: 10-year follow-up. J Urol 2000;163:442-445.

-3 Huang WC, Levey AS, Serio AM, Snyder M, Vickers AJ, Raj GV, et al: Chronic kidney disease after nephrectomy in patients with renal cortical tumours: a retrospective cohort study. Lancet Oncol 2006;7:735-740.

4 Gill IS, Desai MM, Kaouk JH, Meraney AM, Murphy DP, Sung GT, et al: Laparoscopic partial nephrectomy for renal tumor: duplicating open surgical techniques. J Urol 2002; 167:469-467; discussion 475-476.

Off-Clamp Partial Nephrectomy:

A Systematic Review and Meta-Analysis
5 Thompson RH, Lane BR, Lohse CM, Leibovich BC, Fergany A, Frank I, et al: Every minute counts when the renal hilum is clamped during partial nephrectomy. Eur Urol 2010; 58:340-345.

6 Hozo SP, Djulbegovic B, Hozo I: Estimating the mean and variance from the median, range, and the size of a sample. BMC Med Res Methodol 2005;5:13.

7 George AK, Herati AS, Srinivasan AK, RaisBahrami S, Waingankar N, Sadek MA, et al: Perioperative outcomes of off-clamp vs. complete hilar control laparoscopic partial nephrectomy. BJU Int 2013;111:E235-E241.

$\checkmark 8$ Guillonneau B, Bermudez H, Gholami S, El Fettouh H, Gupta R, Adorno Rosa J, et al: Laparoscopic partial nephrectomy for renal tumor: single-center experience comparing clamping and no clamping techniques of the renal vasculature. J Urol 2003;169:483-486.
-9 Kobayashi Y, Saika T, Manabe D, Nasu Y, Kumon H: The benefits of clamping the renal artery in laparoscopic partial nephrectomy. Acta Med Okayama 2008;62:269-273.

10 Kondo T, Nakazawa H, Ito F, Onitsuka S, Ryoji O, Yago R, et al: Impact of arterial occlusion during partial nephrectomy on residual renal function: an evaluation with technetium-99m-dimercaptosuccinic acid scintigraphy. Int J Urol 2002;9:435-440.

11 Koo HJ, Lee DH, Kim IY: Renal hilar control during laparoscopic partial nephrectomy: to clamp or not to clamp. J Endourol 2010;24: 1283-1287.

12 Kopp RP, Mehrazin R, Palazzi K, Bazzi WM, Patterson AL, Derweesh IH: Factors affecting renal function after open partial nephrectomy - a comparison of clampless and clamped warm ischemic technique. Urology 2012;80:865-870. 
13 Martin GL, Warner JN, Nateras RN, Andrews PE, Humphreys MR, Castle EP: Comparison of total, selective, and nonarterial clamping techniques during laparoscopic and robot-assisted partial nephrectomy. J Endourol 2012;26:152-156.

-14 Nadu A, Kitrey N, Mor Y, Golomb J, Ramon J: Laparoscopic partial nephrectomy: is it advantageous and safe to clamp the renal artery? Urology 2005;66:279-282.

15 Petrasz P, Slojewski M, Sikorski A: Impact of 'non-clamping technique' on intra- and postoperative course after laparoscopic partial nephrectomy. Wideochir Inne Tech Malo Inwazyjne 2012;7:275-279.

-16 Porpiglia F, Bertolo R, Morra I, Fiori C: Clampless laparoscopic partial nephrectomy: a step towards a harmless nephron-sparing surgery? Int Braz J Urol 2012;38:480488.

17 Smith GL, Kenney PA, Lee Y, Libertino JA: Non-clamped partial nephrectomy: techniques and surgical outcomes. BJU Int 2011; 107:1054-1058.

18 Tanagho YS, Bhayani SB, Sandhu GS, Vaughn NP, Nepple KG, Figenshau RS: Renal functional and perioperative outcomes of off-clamp versus clamped robot-assisted partial nephrectomy: matched cohort study. Urology 2012;80:838-843.

19 Thompson RH, Lane BR, Lohse CM, Leibovich BC, Fergany A, Frank I, et al: Comparison of warm ischemia versus no ischemia during partial nephrectomy on a solitary kidney. Eur Urol 2010;58:331-336.
20 Wszolek MF, Kenney PA, Lee Y, Libertino JA: Comparison of hilar clamping and nonhilar clamping partial nephrectomy for tumours involving a solitary kidney. BJU Int 2011;107:1886-1892.

-21 Kang N, Niu Y, Zhang J, Wang J, Tian X, Yan $\mathrm{Y}$, et al: Intraoperative ultrasonography: a useful tool in retrolaparoscopic nephronsparing surgery. Urol Int 2012;88:338-342.

-22 Nadler RB, Perry KT, Smith ND: Hybrid laparoscopic and robotic ultrasound-guided radiofrequency ablation-assisted clampless partial nephrectomy. Urology 2009;74:202205.

23 Baumert H: Editorial comment. Laparoscopic partial nephrectomy with 'on-demand' clamping reduces warm ischemia time. Eur Urol 2007;52:809-810.

24 Nguyen MM, Gill IS: Halving ischemia time during laparoscopic partial nephrectomy. J Urol 2008;179:627-632; discussion 632.

25 Gill IS, Patil MB, Abreu AL, Ng C, Cai J, Berger A, et al: Zero ischemia anatomical partial nephrectomy: a novel approach. J Urol 2012; 187:807-814.

26 Shao P, Tang L, Li P, Xu Y, Qin C, Cao Q, et al: Precise segmental renal artery clamping under the guidance of dual-source computed tomography angiography during laparoscopic partial nephrectomy. Eur Urol 2012; 62:1001-1008.
27 Shao P, Qin C, Yin C, Meng X, Ju X, Li J, et al: Laparoscopic partial nephrectomy with segmental renal artery clamping: technique and clinical outcomes. Eur Urol 2011;59: 849-855.

28 Gong EM, Zorn KC, Orvieto MA, Lucioni A, Msezane LP, Shalhav AL: Artery-only occlusion may provide superior renal preservation during laparoscopic partial nephrectomy. Urology 2008;72:843-846.

29 Landman J, Rehman J, Sundaram CP, Bhayani S, Monga M, Pattaras JG, et al: Renal hypothermia achieved by retrograde intracavitary saline perfusion. J Endourol 2002; 16:445-449.

30 Gill IS, Abreu SC, Desai MM, Steinberg AP, Ramani AP, Ng C, et al: Laparoscopic ice slush renal hypothermia for partial nephrectomy: the initial experience. J Urol 2003;170: 52-56.

31 Kobayashi K, Saito T, Kitamura Y, Nobushita T, Kawasaki T, Hara N, et al: The RENAL nephrometry score and the PADUA classification for the prediction of perioperative outcomes in patients receiving nephronsparing surgery: feasible tools to predict intraoperative conversion to nephrectomy. Urol Int 2013;91:261-268.

32 Lane BR, Russo P, Uzzo RG, Hernandez AV, Boorjian SA, Thompson RH, et al: Comparison of cold and warm ischemia during partial nephrectomy in 660 solitary kidneys reveals predominant role of non-modifiable factors in determining ultimate renal function. J Urol 2011;185:421-427. 